\title{
CHEMOSPHERE
}

\section{Chromium adsorption by aligned carbon nanotubes supported ceria nanoparticles}

\author{
Ze-Chao Di ${ }^{\text {a,*}}{ }^{\text {, Jun Ding }}{ }^{\text {a }}$, Xian-Jia Peng ${ }^{b}$, Yan-Hui Li ${ }^{a}$, \\ Zhao-Kun Luan ${ }^{\mathrm{b}}$, Ji Liang ${ }^{\mathrm{a}}$ \\ a Department of Mechanical Engineering, Tsinghua University, Beijing 100084, China \\ ${ }^{\mathrm{b}}$ State Key Laboratory of Environmental Aquatic Chemistry, Research Center for Eco-Environmental Sciences, \\ Chinese Academy of Sciences, Beijing 100085, China
}

Received 21 April 2004; received in revised form 21 June 2004; accepted 24 June 2004

\begin{abstract}
Ceria nanoparticles supported on aligned carbon nanotubes $\left(\mathrm{CeO}_{2} / \mathrm{ACNTs}\right)$, a novel adsorbent for $\mathrm{Cr}(\mathrm{VI})$ from drinking water, were prepared by chemical reaction of $\mathrm{CeCl}_{3}$ with $\mathrm{NaOH}$ in aligned carbon nanotube solution and subsequent heat treatment. The best $\mathrm{Cr}(\mathrm{VI})$ adsorption effect of $\mathrm{CeO}_{2} / \mathrm{ACNTs}$ occurs at a pH range of 3.0-7.4. The largest adsorption capacity of $\mathrm{CeO}_{2} / \mathrm{ACNT}$ s reaches $30.2 \mathrm{mg} \mathrm{g}^{-1}$ at an equilibrium $\mathrm{Cr}(\mathrm{VI})$ concentration of $35.3 \mathrm{mg}^{-1}$ at $\mathrm{pH}$ 7.0. The experiment results suggest that $\mathrm{CeO}_{2} / \mathrm{ACNTs}$ have great potential applications in environmental protection. (C) 2005 Elsevier Ltd. All rights reserved.
\end{abstract}

Keywords: Aligned carbon nanotubes; Langmuir isotherm; Freundlich isotherm; Electron microscopy; Surface charge

\section{Introduction}

Chromium is one of the extremely toxic heavy metals found in various industrial wastewaters (Alves et al., 1993). Several processes have been reported to remove $\mathrm{Cr}(\mathrm{VI})$ from aqueous solutions, such as chemical precipitation, membrane filtration, ion exchange and adsorption, the latter process is a more useful method for metal removal than the other processes. The absorbents commonly recommended for $\mathrm{Cr}(\mathrm{VI})$ removal are alumina, silica (Yabe and Oliveira, 2003) and activated carbon (Selvi et al., 2001). Wasay et al. (1996a) reported that hydrous oxides of rare earth elements exhibit high-adsorption capacity for anions.

\footnotetext{
* Corresponding author. Tel./fax: +86 1062782413.

E-mail address: dizechao00@mails.tsinghua.edu.cn (Z.-C. Di).
}

Carbon nanotubes (CNTs) are increasingly attracting interest since their discovery (Iijima, 1991). Their small sizes, large surface area, high mechanical strength and remarkable electrical conductivities indicate their tremendous potential for future engineering applications, such as hydrogen storage (Dillon et al., 1997), field emission (Wang et al., 1998), catalyst supports (Planeix et al., 1994) and composite materials (Ajayan et al., 1994), etc. Studies of CNTs using as adsorbents have also been reported extensively. Long and Yang (2001) found that CNTs were superior absorbent for dioxin removal. Our previous work ( $\mathrm{Li}$ et al., 2002) suggested that carbon nanotubes show high efficiency for $\mathrm{Pb}^{2+}$ removal after oxidation treatment with nitric acid. $\mathrm{Li}$ et al. (2001) reported that CNTs supported metal oxides such as amorphous alumina had higher fluoride adsorption capacity which was about 13.5 times higher than that of AC-300 carbon and four times higher than that of 
$\mathrm{Al}_{2} \mathrm{O}_{3}$. Here we used aligned carbon nanotubes (ACNTs) as supports to deposit $\mathrm{CeO}_{2}$ and found that $\mathrm{CeO}_{2} / \mathrm{ACNTs}$ exhibited excellent characteristics for removing $\mathrm{Cr}(\mathrm{VI})$ from drinking water.

\section{Experiment section}

ACNTs were prepared by catalytic decomposition of hydrocarbon as described elsewhere (Cao et al., 2001). Scanning electron microscopy images (Fig. 1a) show that the carbon nanotube alignment is uniform and lengths are about $200 \mu \mathrm{m}$ and their diameters range from 20 to $80 \mathrm{~nm}$. The as-prepared ACNTs were then immersed in concentrated nitric acid and hydrofluoric acid to dissolve the catalyst particles and then washed with deionized water. The dried ACNTs were ground by ball milling to break the ACNTs into short pieces and refluxed with mixed solution of nitric acid and sulfuric acid at $140^{\circ} \mathrm{C}$ for $1 \mathrm{~h}$ to introduce functional groups, such as hydroxyl $(-\mathrm{OH})$ and carboxyl $(-\mathrm{COOH})$ on the surface of the ACNTs (Jia et al., 1999). Finally they were filtered with a ceramic filter until the $\mathrm{pH}$ value of the ACNTs solution reached 7.0.

All chemicals used were analytical grade. The ACNTs were dispersed into distilled water and agitated with a magnetic agitator. The $\mathrm{CeCl}_{3}\left(0.035 \mathrm{~g} \mathrm{ml}^{-1}\right)$ solution was added into ACNTs solution drop by drop. After the mixture was agitated for $1 \mathrm{~h}, \mathrm{NaOH}$ solution with a concentration of $0.5 \mathrm{wt} . \%$ was titrated into mixture until the $\mathrm{pH}$ value of the mixture solution reached 8.5 . The mixture solution was then dried up and heated in air at $4500^{\circ} \mathrm{C}$ for $20 \mathrm{~min}$. The nanosized ceria particles supported on ACNTs $\left(\mathrm{CeO}_{2} / \mathrm{ACNTs}\right)$ can be prepared. The relevant chemical reactions can be expressed as follows:

$\mathrm{CeCl}_{3}+\mathrm{NaOH}+\mathrm{ACNTs} \rightarrow \mathrm{NaCl}+\mathrm{Ce}(\mathrm{OH})_{3} /$ ACNTs

$\mathrm{Ce}(\mathrm{OH})_{3} / \mathrm{ACNTs} \rightarrow \mathrm{Ce}_{2} \mathrm{O}_{3} / \mathrm{ACNTs}+\mathrm{H}_{2} \mathrm{O}$

$\mathrm{Ce}_{2} \mathrm{O}_{3} / \mathrm{ACNTs}+\mathrm{O}_{2} \rightarrow \mathrm{CeO}_{2} / \mathrm{ACNTs}$
The TEM image of $\mathrm{CeO}_{2} / \mathrm{ACNT}$ is shown in Fig. 1b. It can be seen that ceria particles are homogeneously spread on the surface of ACNTs. The particle size is about $6 \mathrm{~nm}$.

The $\mathrm{Cr}(\mathrm{VI})$ solution used in the batch sorption experiments was prepared by dissolving potassium dichromate $\left(\mathrm{K}_{2} \mathrm{Cr}_{2} \mathrm{O}_{7}\right)$ in deionized water. The adsorption experiments were carried out in glass tubes at room temperature $\left(25^{\circ} \mathrm{C}\right)$ by putting $0.1 \mathrm{~g} \mathrm{CeO}_{2} / \mathrm{ACNTs}$ in $100 \mathrm{ml} \mathrm{K}_{2} \mathrm{Cr}_{2} \mathrm{O}_{7}$ solution. The effect of different $\mathrm{pH}$ values on $\mathrm{Cr}(\mathrm{VI})$ adsorption was studied. The $\mathrm{pH}$ values were adjusted with $0.1 \mathrm{M} \mathrm{HNO}_{3}$ or $0.1 \mathrm{M} \mathrm{NaOH}$ solutions and all the $\mathrm{pH}$ measurements were carried out using an Elico-Digital pH meter (Model CL-51). The glass tubes were mounted on a shaker (HZQ-C) and shaken for $24 \mathrm{~h}$. The suspension was filtered through $0.45 \mu \mathrm{m}$ membrane filter. The concentration of $\mathrm{Cr}(\mathrm{VI})$ ions in solution was determined colorimetrically with the diphenylcarbazide method. The amount of $\mathrm{Cr}(\mathrm{VI})$ adsorption on the $\mathrm{CeO}_{2} / \mathrm{ACNTs}$ was determined as the difference between the initial concentration and the equilibrium concentration.

\section{Results and discussion}

\subsection{Effect of $p H$}

$\mathrm{pH}$ is the most important parameter controlling the metal ion adsorption process. The effects of $\mathrm{pH}$ for $\mathrm{Cr}(\mathrm{VI})$ removal by $\mathrm{CeO}_{2} / \mathrm{ACNTs}$ is shown in Fig. 2 (the initial concentration of $\mathrm{Cr}$ ion $C_{\mathrm{i}}=10.0 \mathrm{mg} \mathrm{l}^{-1}$ ). It was apparent that $\mathrm{Cr}(\mathrm{VI})$ was strongly adsorbed at $\mathrm{pH} 3.0-7.4$ and declined very sharply at $\mathrm{pH}<3.0$ and $\mathrm{pH}>7.4$.

Weng et al. (1997) found that the distribution of the $\mathrm{Cr}(\mathrm{VI})$ species in solution depends on $\mathrm{pH}$ : at $\mathrm{pH}$ value under 3.0, the dichromate $\left(\mathrm{Cr}_{2} \mathrm{O}_{7}^{2-}\right)$ and acid chromate $\left(\mathrm{HCrO}_{4}^{-}\right)$ion species coexist in solution. Since there are many functional groups, such as $-\mathrm{OH}$ and $-\mathrm{COOH}$ on the surface of the ACNTs after oxidation with mixed
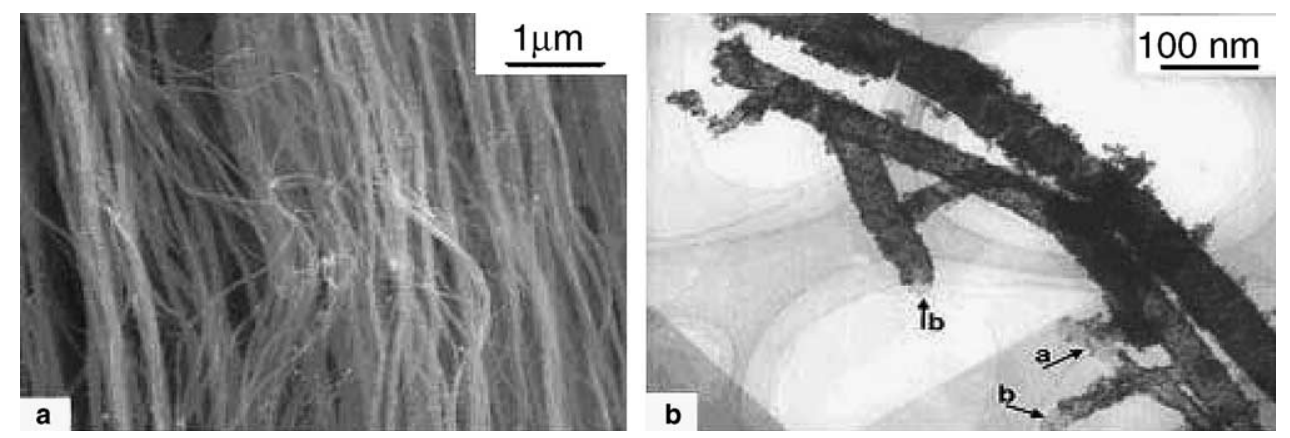

Fig. 1. (a) SEM images of ACNTs. (b) TEM image of $\mathrm{CeO}_{2} / \mathrm{ACNTs}$. 


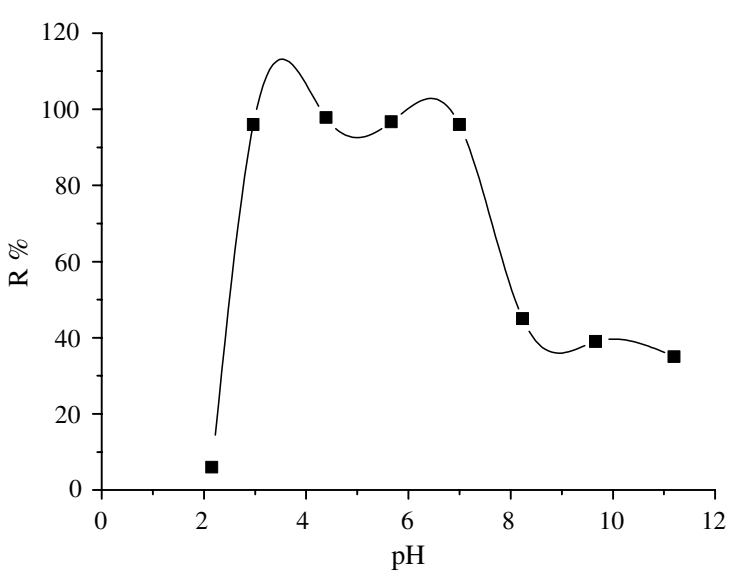

Fig. 2. Adsorption efficiency for $\mathrm{Cr}(\mathrm{VI})$ of $\mathrm{CeO}_{2} / \mathrm{ACNTs}\left(R^{\%} \%\right)$ as a function of $\mathrm{pH}$ values $\left(C_{\mathrm{i}}=10.0 \mathrm{mg} \mathrm{l}^{-1}\right.$ and $\left.25^{\circ} \mathrm{C}\right)$.

solution of nitric acid and sulfuric acid, it is supposed that $\mathrm{CeO}_{2} / \mathrm{ACNT}$ are the carbonaceous material as $\mathrm{C}_{x} \mathrm{OH}$. In the presence of a reducing substrate $\left(\mathrm{C}_{x} \mathrm{OH}\right)$, $\mathrm{Cr}(\mathrm{VI})$ species are quickly reduced into $\mathrm{Cr}(\mathrm{III})$ ions as shown in Eqs. (4) and (5):

$$
\begin{aligned}
& 3 \mathrm{C}_{x} \mathrm{OH}+\mathrm{Cr}_{2} \mathrm{O}_{7}^{2-}+4 \mathrm{H}^{+} \\
& \quad \rightarrow 3 \mathrm{C}_{x} \mathrm{O}+\mathrm{HCrO}_{4}^{-}+\mathrm{Cr}^{3+}+3 \mathrm{H}_{2} \mathrm{O} \\
& 3 \mathrm{C}_{x} \mathrm{OH}+\mathrm{HCrO}_{4}^{-}+4 \mathrm{H}^{+} \rightarrow 3 \mathrm{C}_{x} \mathrm{O}+\mathrm{Cr}^{3+}+4 \mathrm{H}_{2} \mathrm{O}
\end{aligned}
$$

where $\mathrm{C}_{x}=$ carbon. $\mathrm{Cr}(\mathrm{III})$ ions are not sorbed or poorly sorbed at these low $\mathrm{pH}$ values. So at $\mathrm{pH}<3.0$ the adsorption capacity is very low. Since the concentration of $\mathrm{H}^{+}$decreases at $\mathrm{pH}>3.0$, the chemical reaction (4) and (5) will not go on any more.

The $\mathrm{pH}$ value at which the Zeta potential equals zero is called the isoelectric point (IEP) and it is used to assess the absorbent surface charge qualitatively. The IEP of the $\mathrm{CeO}_{2} / \mathrm{ACNT}$ is 7.4 (Malvern zetameter, model zetasizer 2000). Many researchers (Wasay et al., 1996b; Tokunaga et al., 1997) have found that the adsorption of anions is the reaction between anions and the hydrous oxides of metal oxides $(-\mathrm{M}-\mathrm{OH})$ on the adsorbent surface. The hydroxylation of cerium oxides supported on ACNTs can form $-\mathrm{Ce}-\mathrm{OH}$ on the surface. At $\mathrm{pH} 3.0$ 7.4, the main oxyanions of $\mathrm{Cr}(\mathrm{VI})$ are $\mathrm{CrO}_{4}^{2-}$ and
$\mathrm{HCrO}_{4}^{-}$ions (Weng et al., 1997) and the surface charge of $\mathrm{CeO}_{2} / \mathrm{ACNTs}$ is positive, consequently, coulombic attraction can readily take place due to the interaction between $\mathrm{Cr}(\mathrm{VI})$ ions and adsorbent, and the possible ion exchange mechanisms for $\mathrm{Cr}(\mathrm{VI})$ removal can be written as follows:

$$
\begin{aligned}
& -\mathrm{Ce}-\mathrm{OH}+\mathrm{CrO}_{4}^{2-} \rightarrow \mathrm{Ce}-\mathrm{CrO}_{4}^{-}+\mathrm{OH}^{-} \\
& -\mathrm{Ce}-\mathrm{OH}+\mathrm{HCrO}_{4}^{-} \rightarrow-\mathrm{Ce}-\mathrm{HCrO}_{4}+\mathrm{OH}^{-}
\end{aligned}
$$

The $\mathrm{Cr}(\mathrm{VI})$ adsorption capacity of $\mathrm{CeO}_{2} / \mathrm{ACNT}$ will decrease at $\mathrm{pH} \geqslant \mathrm{FEP}$ due to neutrally or negatively charged surface of the adsorbent. In addition, at $\mathrm{pH}>8.0$ large numbers of $\mathrm{OH}^{-}$in aqueous solution will compete with $\mathrm{Cr}(\mathrm{VI})$ for the active sites.

\subsection{Adsorption isotherms}

The adsorption isotherms of $\mathrm{Cr}(\mathrm{VI})$ adsorption by $\mathrm{CeO}_{2}$ /ACNTs at different $\mathrm{pH}$ values are illustrated in Fig. 3. All batch experimental data were fitted to the isotherm models of Langmuir and Freundlich using a method of least squares based on an optimization algorithm.

Parameter values for the Langmuir and Freundlich isotherm are listed in Table 1.

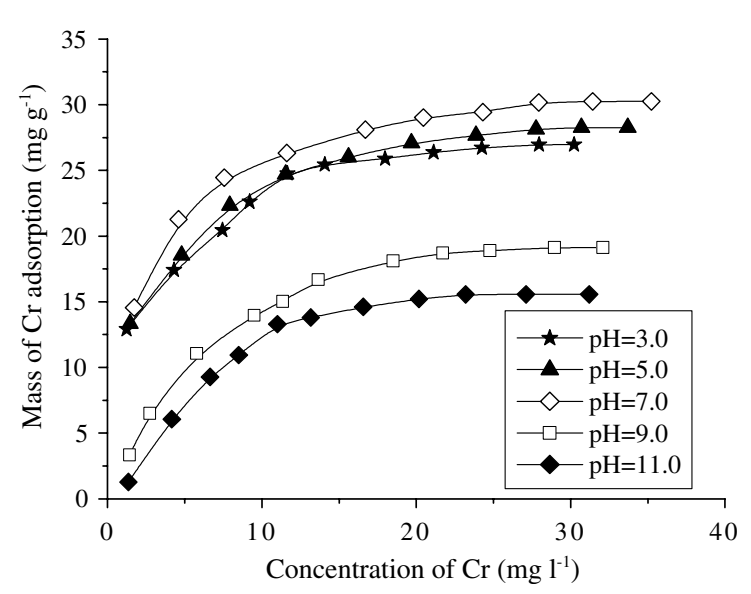

Fig. 3. Adsorption isotherms of $\mathrm{CeO}_{2} / \mathrm{ACNT}$ as a function of $\mathrm{pH}$ values $\left(25^{\circ} \mathrm{C}\right)$.

Table 1

Langmuir and Freundlich isotherm parameters for $\mathrm{Cr}(\mathrm{VI})$ adsorption by $\mathrm{CeO}_{2} / \mathrm{ACNTs}$

\begin{tabular}{rlllllll}
\hline $\mathrm{pH}$ & \multicolumn{2}{l}{ Langmuir } & & & \multicolumn{2}{l}{ Freundlich } \\
\cline { 2 - 3 } & $q_{m}$ & $K_{\mathrm{L}}$ & $r^{2}$ & & $n$ & $K_{\mathrm{F}}$ & $r^{2}$ \\
\hline 3.0 & 26.81 & 0.7064 & 0.9264 & 4.01 & 12.5021 & 0.9685 \\
5.0 & 28.49 & 0.5783 & 0.9590 & 4.00 & 12.6493 & 0.9745 \\
7.0 & 31.55 & 0.490 & 0.9958 & 4.16 & 13.9684 & 0.9488 \\
9.0 & 26.04 & 0.3181 & 0.9911 & 2.80 & 8.0149 & 0.9697 \\
11.0 & 23.26 & 0.2679 & 0.9893 & 1.75 & 6.2115 & 0.9497 \\
\hline
\end{tabular}


The experimental results based on the adsorption isotherms (Fig. 3) show that the best $\mathrm{Cr}(\mathrm{VI})$ adsorption occurs at $\mathrm{pH}$ 3.0-7.0. This is supported on the shape of the curve in Fig. 2. It can be seen from Fig. 3 that the mass of $\mathrm{Cr}(\mathrm{VI})$ adsorption for $\mathrm{CeO}_{2} / \mathrm{ACNT}$ at $\mathrm{pH}$ 7.0 reaches $30.3 \mathrm{mg} \mathrm{g}^{-1}$ at equilibrium concentration of $31.4 \mathrm{mg} \mathrm{l}^{-1}$. The $\mathrm{Cr}(\mathrm{VI})$ adsorption of $\mathrm{CeO}_{2} / \mathrm{ACNTs}$ decreases at $\mathrm{pH}$ value of 9.0 and 11.0, which is $19.1 \mathrm{mg} \mathrm{g}^{-1}$ and $15.6 \mathrm{mg} \mathrm{g}^{-1}$, respectively. The wide range of $\mathrm{pH}$ values makes $\mathrm{CeO}_{2} / \mathrm{ACNT}$ good materials for $\mathrm{Cr}(\mathrm{VI})$ removal.

\subsection{Comparison with other adsorbents}

$\mathrm{Cr}$ (VI) adsorption isotherms of $\mathrm{CeO}_{2} / \mathrm{ACNT}$ s were compared with ball-milled ACNTs, activated carbon EA-200 (Fujian Jianou ZhiXing Activated Carbon Co., Ltd., China) and $\gamma-\mathrm{Al}_{2} \mathrm{O}_{3}$.

It is can be seen from Fig. 4 that the adsorption capacity for $\mathrm{CeO}_{2} / \mathrm{ACNTs}\left(28.3 \mathrm{mg} \mathrm{g}^{-1}\right)$ is about 1.5 , 2.0 and 1.8 times higher than that of the activated carbon, $\mathrm{Al}_{2} \mathrm{O}_{3}$ and the ball-milled ACNTs $(11.3,9.3$ and $10.2 \mathrm{mg} \mathrm{g}^{-1}$ ), respectively, at equilibrium $\mathrm{Cr}(\mathrm{VI})$ concentration of $33.0 \mathrm{mg} \mathrm{l}^{-1}$.

\subsection{Mechanism of $\mathrm{Cr}$ (VI) adsorption by $\mathrm{CeO}_{2} / A C N T s$}

The most important factor in the excellent $\mathrm{Cr}(\mathrm{VI})$ adsorption capacity of $\mathrm{CeO}_{2} / \mathrm{ACNT}$ s is the specific affinity between hydrous oxides of rare earth element $\mathrm{Ce}$ and $\mathrm{Cr}(\mathrm{VI})$ anions as shown in Eqs. (6) and (7). The small size of $\mathrm{CeO}_{2}$ particles and their uniform distribution on the surface of ACNTs should contribute to the high $\mathrm{Cr}(\mathrm{VI})$ adsorption.

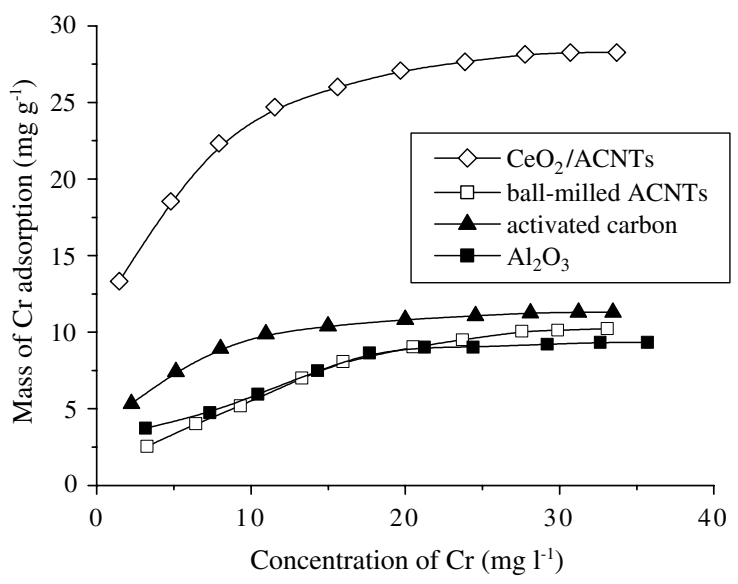

Fig. 4. Adsorption isotherm of $\mathrm{Cr}(\mathrm{VI})$ on $\mathrm{CeO}_{2} / \mathrm{ACNTs}$ compared with activated carbon, $\mathrm{Al}_{2} \mathrm{O}_{3}$ and ball-milled ACNTs (at $\mathrm{pH}=5.0$ and $25^{\circ} \mathrm{C}$ ).
It is well known that the ACNTs prepared by CVD have many defects. These defects can offer active sites for $\mathrm{Cr}(\mathrm{VI})$ adsorption on the outer surfaces of ACNTs. The inner cavities and the opened ends (as shown by arrows $\mathrm{a}$ and $\mathrm{b}$ in Fig. 1b) composed by inter-aligned nanotube space may also contribute to the effective adsorption of $\mathrm{Cr}(\mathrm{VI})$. The ball-mill process will shorten ACNTs and increase the surface area of ACNTs. This is supported on the curve of the ball-milled ACNTs in Fig. 4. On the other hand, oxidation treatment by oxidized acid can cause an increase in ion-exchange capacity of ACNTs (Li et al., 2001).

\section{Conclusion}

Nanoparticles $\mathrm{CeO}_{2}$ supported on ACNTs can be prepared by chemical reaction of $\mathrm{CeCl}_{3}$ and $\mathrm{NaOH}$ in ACNTs solution and subsequent heat treatment. Adsorption isotherms for $\mathrm{Cr}(\mathrm{VI})$ adsorption onto $\mathrm{CeO}_{2}$ /ACNTs from drinking water have been studied at different $\mathrm{pH}$ values of the solution and found that $\mathrm{CeO}_{2}$ /ACNTs exhibited high $\mathrm{Cr}(\mathrm{VI})$ adsorption efficiency from water in a broad range of $\mathrm{pH}$ values between 3.0 and 7.4. The adsorption capacity of the $\mathrm{CeO}_{2} / \mathrm{ACNT}$ is 1.5 times higher than that of the activated carbon, 2.0 times higher than that of $\mathrm{Al}_{2} \mathrm{O}_{3}$ and 1.8 times higher than that of ball-milled ACNTs. The high adsorption capacity, the wide range of $\mathrm{pH}$ values make $\mathrm{CeO}_{2} / \mathrm{ACNT}$ a good candidate material for $\mathrm{Cr}$ (VI) removal, especially from drinking water.

\section{References}

Ajayan, P.M., Stephan, O., Colliex, C., Trauth, D., 1994. Aligned carbon nanotube arrays formed by cutting a polymer resin-nanotube composite. Science 65, 1212-1214.

Alves, M.M., Ceca, C.G.G., de Carvalho, R.G., Castanheira, J.M., Periera, M.C.S., Vasconcelos, L.A.T., 1993. Chromium removal in tannery wastewaters polishing by Pinus syivestris bark. Wat. Res. 27, 1333-1338.

Cao, A., Zhu, H., Zhang, X., Li, X., Ruan, D., Xu, C., Wei, B., Liang, J., 2001. Hydrogen storage of dense-aligned carbon nanotubes. Chem. Phys. Lett. 342, 510-514.

Dillon, A.C., Jones, K.M., Bekkedahl, T.A., Kiang, C.H., Bethune, D.S., Heben, D.S., 1997. Storage of hydrogen in single-walled carbon nanotubes. Nature 386, 377-379.

Iijima, S., 1991. Helical microtubules of graphitic carbon. Nature 354, 56-58.

Jia, Z., Wang, Z., Liang, J., Wei, B., Wu, D., 1999. Production of short multi-walled carbon nanotubes. Carbon 37, 903906.

Li, Y.H., Wang, S., Cao, A., Zhao, D., Zhang, X., Xu, C., Luan, Z., Dianbo, R., Liang, J., Wu, D., Wei, B., 2001. Adsorption of fluoride from water by amorphous alumina supported on carbon nanotubes. Chem. Phys. Lett. 350, $412-416$. 
Li, Y.H., Wang, S., Wei, J., Zhang, X., Xu, C., Luan, Z., Wu, D., Wei, B., 2002. Lead adsorption on carbon nanotubes. Chem. Phys. Lett. 357, 263-266.

Long, R.Q., Yang, R.T., 2001. Carbon nanotubes as superior sorbent for dioxin removal. J. Am. Chem. Soc. 123, 20582059.

Planeix, J.M., Coustel, N., Coq, B., Brotons, V., Kumbhar, P.S., Dutarte, R., Geneste, P., Bernier, P., Ajayan, P.M., 1994. Application of carbon nanotubes as supports in heterogeneous catalysis. J. Am. Chem. Soc. 16, 7935-7936.

Selvi, K., Pattabhi, S., Kadirvelu, K., 2001. Removal of Cr(VI) from aqueous solution by adsorption onto activated carbon. Bioresour. Technol. 80, 87-89.

Tokunaga, S., Wasay, S.A., Park, S.W., 1997. Removal of $\operatorname{arsenic}(\mathrm{V})$ ion from aqueous solutions by lanthanum compounds. Wat. Sci. Technol. 35, 71-78.
Wang, Q.H., Setlur, A.A., Lauerhaas, J.M., Dai, J.Y., Seelig, E.W., Chang, R.P.H., 1998. A nanotube-based field-emission flat panel display. Appl. Phys. Lett. 72, 2912-2913.

Wasay, S.A., Haron, M.J., Tokunaga, S., 1996a. Adsorption of fluoride, phosphate, and arsenate ions on lanthanumimpregnated silica gel. Wat. Environ. Res. 68, 295-300.

Wasay, S.A., Haron, J., Uchiumi, A., Tokunaga, S., 1996 b. Removal of arsenate and arsenate ions from aqueous solution by basic yttrium carbonate. Wat. Res. 30, 11431148 .

Weng, C.H., Wang, J.H., Huang, C.P., 1997. Adsorption of $\mathrm{Cr}(\mathrm{VI})$ onto $\mathrm{TiO}_{2}$ from dilute aqueous solutions. Wat. Sci. Technol. 35, 55-62.

Yabe, M.J.S., Oliveira, E., 2003. Heavy metals removal in industrial effluents by sequential adsorbent treatment. Adv. Environ. Res. 7, 263-272. 